\title{
Soil Conservation in Tropical Africa
}

\section{By Dr. L. Dudley Stamp, director of the Land Utilisation Survey of Britain}

$\mathrm{T}$ HE attention which has recently been given to the widespread and serious nature of soil erosion in the African continent has perhaps insufficiently emphasized two aspects of the problem. One is that the serious and rapid erosion is of recent growth-not only in large measure consequent upon the control of the continent by Europeans but also actually in danger of being increased by the very measures designed to combat it. The other is that the African cultivator has already evolved over large areas a system of farming designed to combat soil erosion and main. tain soil fertility, and that the essential need is to encourage and develop this system rather than to supersede it. A recent tour in Nigeria has convinced me that the African system may hold the key to the solution of some of the most urgent problems of soil erosion in America and elsewhere.

Prior to the European partition of tropical Africa, internecine strife and the incidence of disease, both epidemic and otherwise, resulted naturally in a limitation of population and of any serious pressure on the land in purely agricultural areas, and prevented overstocking both by man and by animals on grazing land. Nowadays, population density in parts of Southern Nigeria reaches more than five hundred to the square mile, whilst the number of cattle in Kenya increased from three to six million between 1920 and 1936 .

In Southern Nigeria, a land of adequate rainfall (60 to 150 inches or more), naturally clothed with high forest but where certainly less than one per cent of virgin forest remains, the land is divided up between the village communities. Each village tract in other lands one would say parish-is held communally and farmed on a well-marked system of rotation, each family returning in the appropriate year to farm its own special portion. The system is often, though wrongly, referred to as 'shifting cultivation', and has even by foresters been called after the system of temporary mountain clearings in Burma a 'Taung-ya' system, which it certainly is not. It is best described as 'bushfallowing', a period of cultivation being followed by a long period of fallow, the only difference from the fallows of temperate lands being that the forest trees form the 'weeds' of the fallows. Seven to ten years (during which the trees grow to thirty feet in height) may be regarded as the normal period of fallow; it is when the pressure on the land is such that the fallow period has to be reduced perhaps even to as little as two years that the system breaks down. When the time comes, the fallow is cleared by burning-better if the burning is as early as possible after the rains so that the fires are not so fierce as to destroy the valued oil palms or completely to destroy the vitality of the stumps left in the ground.

Southern Nigeria is mainly tsetse infested: cattle are entirely absent over large areas and cultivation is entirely by hand-by the hoe. A family can cultivate two or three acres in this way and produce an adequate supply of the staple food-yams-together with limited quantities of cassava (manioc), corn (maize) and a supply of vegetables in the little garden plot (permanently cultivated) round the hut itself. Thus at any given time the village tract appears to be a series of tiny patches of cultivation in the midst of ragged, untidy second-growth forest of varied age. The patches themselves are a series of mounds or of yam hills (in which the yams or cassava are planted), a few stalks of maize or a few beans or gourds growing in the intervening hollows, and stumps of trees still remaining. Weeds are by no means absent, but the soil is protected. If some of the finer fractions are washed out, they are held up by the neighbouring tract of woodland. If Western ideals of ploughing, extensive clearing, weeding and single cropping were introduced, the soil would immediately be subject to serious erosion from which it is at the moment free. The Agricultural Department in Nigeria has rightly recognized this, and is concentrating its attention on the improvement of the present system by green manuring (by leguminous crops) to replace part of the fallow, early burning to prevent serious destruction by fire, and the improvement in quality and yield of the crops grown especially those which may serve as additional cash crops (citrus, cocoa, oil palm, cotton, kola nuts, etc.) and supply the African with the money he needs for taxes, bicycles, travelling, clothing and the various demands coincident with an increased standard of living.

Northern Nigeria consists of large emirates in which the emir holds the land in trust for his people. The cultivators are his tenants, though often holding the land indirectly through the district headmen. The rainfall ranges from about 25 inches along the northern border to 60 inches in the south, and comes essentially in the wet 


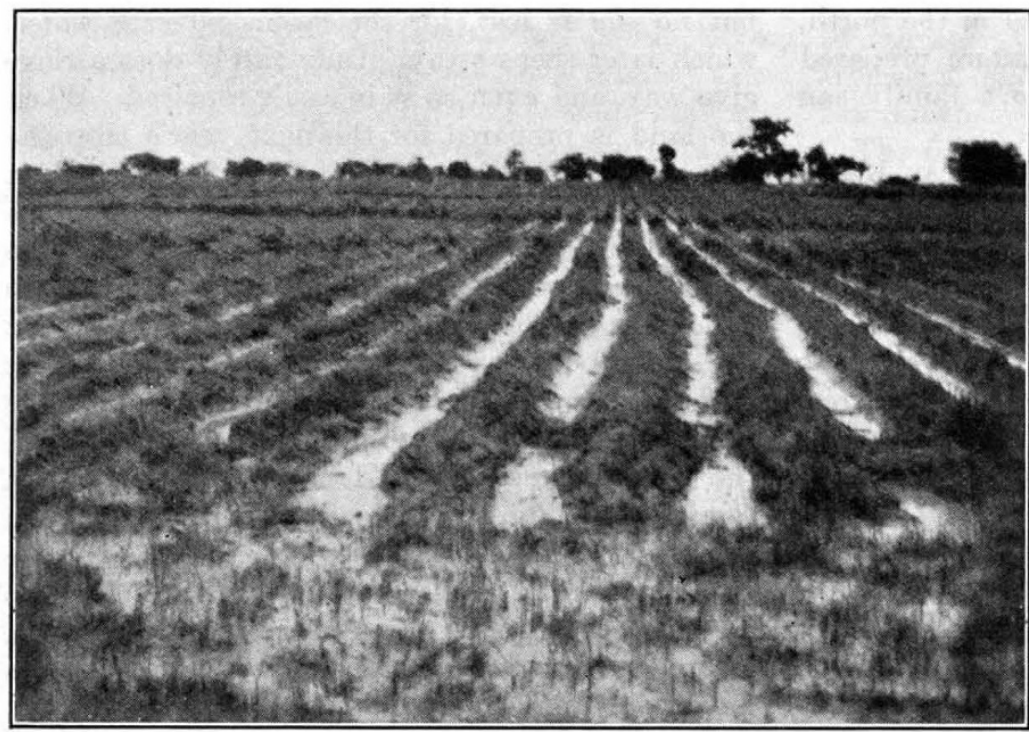

Fig. 1.

The introduction of THE PLOUGH IS LIKELy to CAUSE EROSION OF this

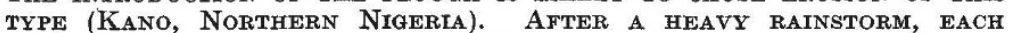
FURROW HAS BECOME AN EROSION CHANNEL CARRYING OFF THE LIGHTER, VALUABLE FRACTION OF THE SOIL.

season from April until October. It falls generally in a succession of storms, four inches in a single night being by no means unusual, and in consequence the predominantly light sandy soils are particularly liable to both sheet and gully erosion. In the dry season the country is parched and bare, and liable, at least in the north, to considerable wind erosion from the dust-laden Harmattan, though the film of fine dust which this wind from the Sahara deposits is not without its value to the soil. The population of the Northern Provinces is irregularly distributed -largely influenced by water supply, with the result that the Geological Survey is at present very actively engaged in wellsiting and well-sinking. There is still a sharp distinction between the nomadic, or seminomadic cattle-rearing Fulani and the settled Hausa cultivators, though the latter are not blind to the value of manure and may even hire the large white-humped zebu cattle from the Fulani for the sake of their droppings.

The natural vegetation of the Northern Provinces is an open savannah forest with an undergrowth of grass, merging northwards into acacia scrub woodland. Uncontrolled grazing by cattle and the large northern goat results in an uneconomic use of the land, of which there would be ample for normal cultivation on the same basis as in the south. Hence it is, very rightly, the policy of the Agricultural Department to introduce and popularize by means of a series of demonstration farms a system of mixed farming, and to fuse the diverse interests in the land of the Fulani and Hausas. The results are gratifying. In 1928 three farmers tried the experiment ; by the end of 1934 the number had increased to 298 , but in the next year it had leapt to 621 . The staple food crops of the north are the tall guinea corn (with stalks valued for roofing and light fencing), other millets (with a less valuable straw), together with some maize, cassava, and a few yams and, locally, rice. The staple cash crops are ground nuts and cotton. The traditional agricultural implement is the hoe, by which a family cultivates about three acres. The Agricultural Department has introduced a light plough throwing up a ridge on either side and which is to be drawn by the cattle now to be kept penned with millet straw bedding (making a manure with binding qualities on the light soils).

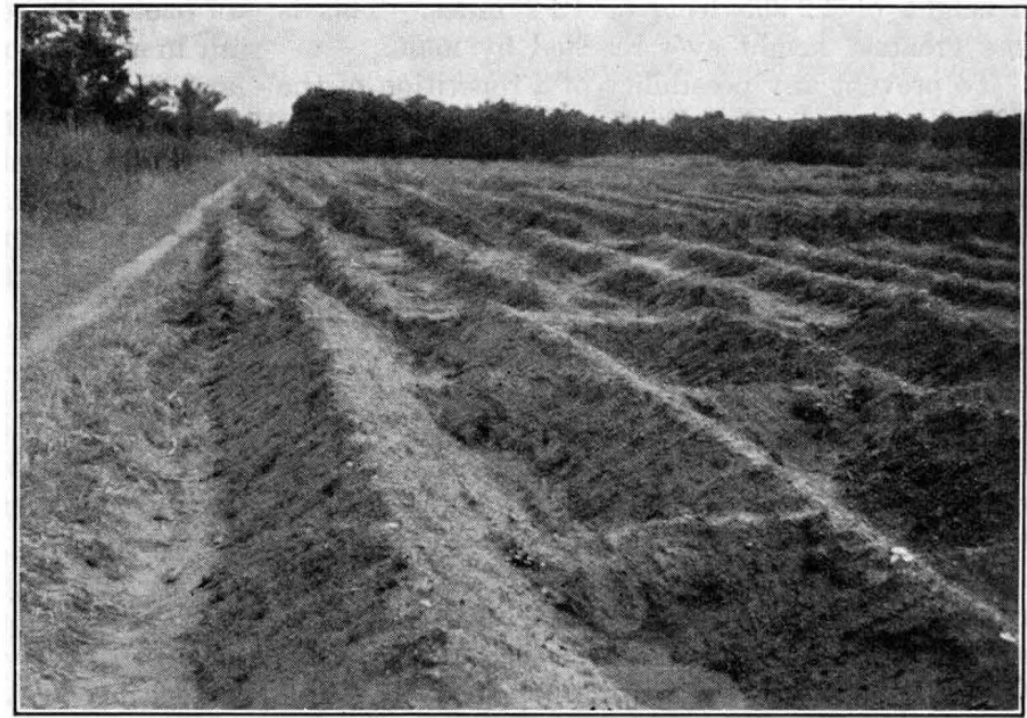

Fig. 2.

The 'RIDGe and Basin' system of native cultivation in Nigkria. The METhod IS VERY EFFEOTIVE IN PREVENTING SOIL EROSION; THE RAIN WATER ACCUMULATES IN THE BASINS AND SEEPS GRADUALLY AWAY. 
The donkeys and goats, so universal in the north, are similarly to be penned and manure prepared in the same way. On this system a family can easily farm twelve acres.

A visit to the experimental farm near Kano, which fortunately took place after nearly four inches of rain had fallen during the night, convinced me that the introduction of the plough into the light land of northern Nigeria is liable to prove a curse which will more than outweigh the blessing conferred by mixed farming. Every furrow is a water course taking off the needed water, every one an incipient erosion gully (Fig. 1). Cross ploughing at intervals is not a remedy a new gully is formed-nor is contour ploughing in this gently undulating plain land sufficient.

Fortunately the local cultivator has already evolved a system which points the way. Instead of the yam hills of the south are ridges (from three to six feet apart and from nine inches to thirty inches high) crossed at intervals by ridges at right angles. Instead of the long straight plough-furrow the result is a series of isolated basins. Into these are swept the finer particles of soil during a storm but no soil is lost, for the basins fill with water, which later seeps away. Only rarely does a ridge give way, and even so it is easily repaired. When the land is prepared for the next year's crop the new ridge takes the place of the previous hollow, so that the soil is well mixed again (Fig. 2). The same result can be achieved by ploughing, if the plough is lifted at intervals. This can readily be done with the light plough used. It is clear that the careful use of cover-crops (a dirty farm is probably better than a well-weeded one), the restoration of fertility by leguminous crops, and the maintenance of wind breaks or 'protection forests' (the Forestry Department in conjunction with the French authorities are to preserve the remaining tracts of scrub and woodland along the international border) are all necessary in addition, as well as the control of areas where erosion is already serious.

If America could invent a plough which will imitate the Nigerian system by replacing the long furrow by a series of isolated elongated basins, one at least of her major problems in the dry lands of the Middle West might be solved.

\section{Observations made in the Highest Stratosphere Flight}

\begin{abstract}
A DETAILED account has been published* of the scientific results of the flight of Explorer II, in which, on November 11, 1935, Major A. W. Stevens and Captain O. A. Anderson ascended to a height of 72,395 feet, or 12.7 miles. This is the greatest height ever reached by man.

To prevent any possibility of a repetition of the disastrous explosion which occurred during the descent of Explorer $I$, it was decided to fill Explorer $I I$ with helium, even although this meant making the balloon considerably larger. The difficulties of filling these huge balloons are very considerable, and the most suitable place that could be found for carrying out this operation was the "Stratosphere Bowl", a natural crater in South Dakota providing complete shelter from the wind. It was intended to make the ascent in June, but when the balloon was half full the fabric burst round the 'rip-panel'. This panel was to be used for rapid deflation when the balloon landed. As a result of this mishap, the balloon had to be considerably modified and was not ready until October, and suitable weather for the ascent did not occur until November.

\footnotetext{
* "The National Geographic Society U.S. Army Air Corps Strato-
} sphere Flight of 1935 in the Balloon 'Explorer II'." (Contributed Technical Papers, Stratosphere Series, No. 2.) (Washington : Nationa] Geographic Society, 1936.)
\end{abstract}

A great many people co-operated to make this flight a success. Measurements were made of the angular distribution of cosmic rays, and the nature of the corpuseles forming them, the distribution of ozone, the conductivity and constitution of the air in the stratosphere, and of the intensity of solar and terrestrial radiation. It was proved that the spores of certain moulds and bacteria can and do exist in the stratosphere, and an attempt was made with rather inconclusive results to find whether the great intensity of cosmic radiation would accelerate mutation in Drosophila.

\section{Cosmic Rays}

The cosmic ray measurements were for the most part carried out under the direction of G. F. Swann. For measuring the angular distribution of cosmic rays a battery of ten cosmic ray telescopes and 210 Geiger counters were used. Five of the telescopes were shielded with lead. The results of this work are illustrated in Fig. 1. In the case of the vertical telescopes, maxima were obtained at the heights corresponding to one and two metres of water below the top of the atmosphere respectively, but these maxima were less pronounced at greater zenith angles. The existence 